\title{
地域社会生活の担い手育成の方法に関する研究 \\ 一地域社会における青少年期の経験の重要性一 \\ Way of Raising Succesors of Community \\ Importance of Experience in Community in Childfood and Youth
}

\author{
井橋朋子* 藍澤宏** 菅原麻衣子** \\ Tomoko IHASHI ${ }^{*}$ Hiroshi AIZAWA** Maiko SUGAWARA** \\ (*東京工業大学大学院 **東京工業大学教育環境創造研究センター) \\ (*Tokyo Institute of Technology ** Research Center for Educational Facilities, Tokyo Institute of Technology)
}

\section{I 研究の背景と目的}

農山村地域では, 一時に比べ若者の流出傾向は 鈍化しているものの, 少子高齢化の進行により, 担い手不足は依然深刻な問題となっている。

しかし，近年こうした状況に対し，故郷の村お こしや産業おこしに励む若者が各地でみられ始め ている。こうした若い世代が地域社会を活気づけ ることにより, 地域社会は社会変化に適応しなが ら維持発展していくことが可能となる。居住地選 択の自由度が進む現代において, 若い担い手の中 には, 地域に住み続けてきた者も一度地域を出て から戻ってきた者もいるが, どちらにしても, 生 まれ育った地域を生活の場として選択した結果で ある。その背景には, 家や地域の状況を含め様々 な事情があるものの, 総体としての価值基準を 個々人が持っていると考えられる。よって, 若い 世代が地域に対して持つ価值基準を明らかにし， その形成過程を捉えることによって, 長期的な視 点に立った担い手の育成を目指寸必要がある。

そこで, 着目すべき事の一つに, 地域における 青少年期の経験が挙げられる。祭りや子供行事, 神社や道路の掃除といった一つ一つの経験は些細 であるが, 地域を知る第一歩としての役割を持つ。

よって, 本研究では, 農山村地域に居住する若 い世代が，地域社会に見出している価值を明らか にし, 同時に青少年期に地域で経験した事との関 連性をみることによって, 地域に対する価值観が 形成される過程を捉える。この一連の流れを通し
て, 今後の地域社会における担い手を育成する方 法を示すことを研究の目的とする。

\section{II 研究の方法}

まず，現在の若い担い手が地域に対して持つ価 值観の特徵を捉え, 次に, その価值観が形成され た背景として, 現在おかれている立場と, 青少年 期に地域で経験したことに着目し, 価値観との関 連性を明らかにする。価值観は, 次世代へ伝え残 そうとする姿勢を通して間接的に把握する。最後 に, 個々人の経験に対する考え方の基になる視点 を詳しく探ることによって, 今後の地域社会の担 い手育成の方法の一端を示す（図 1)。

また, 地域社会における経済的基盤は重要であ り, その担い手確保も課題であるが，個別的な背 景の影響があること, 及び拠点確保が重要である という視点に立ち, 本研究では社会生活の側面に 特化して考察を進めることとする。

具体的な項目設定は以下の通りである。

第一に, 地域社会の中で子供が育つ場として, 暮らしの基本を学ぶ《家》, 互助関係を学ぶ《近 隣》, 共同体における役割を学ぶ《地域》を想定 した。詳細な項目としては, 《地域》では, その 構成要素として[環境][文化][安全] [組織]の 4 側面から(1)環境管理, (2)農環境整備, (3)祭り, (4) 祭りの準備, (5)治安活動, (6)防災活動, (7)子供の 行事, (8)地域組織活動, (9)地域組織運営の 9 項目, 《近隣》では[伝統] [教育]の側面から(10近隣での 
行事, (11)節句や就学の祝い, (12)子供のしつけ, (13) 生活の知恵や昔話の語り継ぎ, 《家》では地域を 知る一端として14近所とのつき合い, [伝統] とし て(15)郷土料理の伝承, (16)盆や正月の支度, の計 16 項目を設定した。各項目について，次世代に 伝えていく事として【必要ない】，【体験させた い: 意向】，【体験させている/させた：実践】， の 3 段階で捉えた。第二に, 現在の若い担い手が 青少年期に地域で経験したことについて, 上記(1) 〜16の 16 項目に加え, 《家》で教える暮らしの 基本である(17)住まいの保全, 18家業の手伝いの 2 項目を設定した。各項目について, 経験の有無と それに対する当時の意見を【十：楽しい，やりが いがある】【ー：面倒だ，わずらわしい】の 2 方 向で捉えた。

最後に, 経験の各項目に対しての視点として, それぞれに見出寸意味を I . 知識の習得, II . 役 割の自営, III. 周囲との協調, IV. 次世代への継 承の 4 段階に設定し， I $\rightarrow$ II : 責任の自覚， II $\rightarrow$ III : 周囲への視野の広がり, III $\rightarrow \mathrm{IV}:$ 次世代への 関心の広がり,という発展性を捉える。

また，地域に対する価值観を捉える上で，個々 人の家, 地域, 社会における立場を考虑するため, 年齢・居住地域・家族構成・地区外での居住経験 · 兄弟の中での立場による違いも検証した。

調査対象地は, 少子高齢化が著しい中山間農業 地域でありながら, 若い世代の活躍もみられ，ま た中心部から山間部まで多様な地域性を含んで いる愛媛県 $K$ 町 0 地区を選定した。調査方法は, 将来地域運営の中核を担う 20 代から 40 代の夫婦 に対するアンケート調査を行った（表 1)。

\section{III 若い担い手が持つ地域に対する価值観}

次世代への継承状況をみることにより, 現在の 若い担い手が持つ地域に対寸る価值観を捉える。

まず，全体の傾向から各項目の特徵を捉える

（図 2）。(1)環境管理，(3)祭り，(7)子供の行事, (14)近所とのつき合いは， 6 割以上が【実践】して おり, O地区において最も重要な地域社会経験と して認識されていることを示す。一方で, (4)祭り の準備, (6)防災, (8)組織活動, (13)昔話の語り継ぎ

\begin{tabular}{|c|c|c|c|c|c|}
\hline \multirow{9}{*}{$\begin{array}{l}\text { 地 } \\
\text { 域 }\end{array}$} & \multirow{2}{*}{ 㻦莧 } & (1)国㙂管理 & 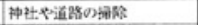 & \multirow{3}{*}{\multicolumn{2}{|c|}{ 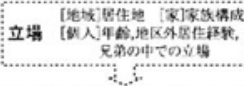 }} \\
\hline & & 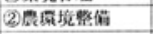 & 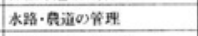 & & \\
\hline & \multirow{2}{*}{ 文化 } & (3)祭b) & 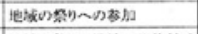 & & \\
\hline & & (4)祭りの相俭 & 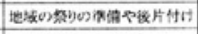 & \multirow{6}{*}{\multicolumn{2}{|c|}{ 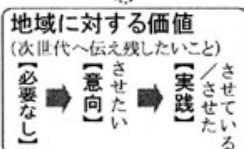 }} \\
\hline & & (5)话安活野 & 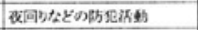 & & \\
\hline & & (6)防災活動 & 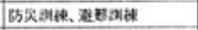 & & \\
\hline & \multirow{3}{*}{ 粗楼 } & (D)供の行来 & சとし去の仿事 & & \\
\hline & & (3)地枝祖棈活㴞 & 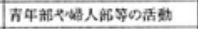 & & \\
\hline & & 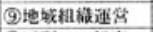 & 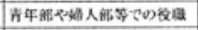 & & \\
\hline & \multirow{2}{*}{ 伝絰 } & (1)近户口゙の行束 & 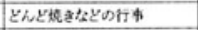 & \multirow{4}{*}{\multicolumn{2}{|c|}{ 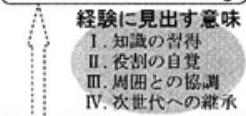 }} \\
\hline & & 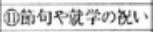 & 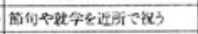 & & \\
\hline & & 13子倛のしつけ & 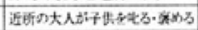 & & \\
\hline & 教育 & 13苪話ツの票り維芑 & 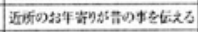 & & \\
\hline \multirow{5}{*}{ 家 } & 象: & ఐ10迁诉とのつを合い & 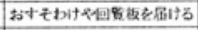 & \multirow{3}{*}{\multicolumn{2}{|c|}{$\begin{array}{l}\text { 青少年期の経験 } \\
\text { 当時の)感想 } \\
\oplus \odot\end{array}$}} \\
\hline & & (15)阷土料理の)伝示 & 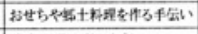 & & \\
\hline & 层絰 & இ然や正月の文度 & 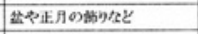 & & \\
\hline & & 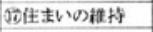 & 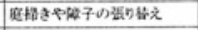 & & つま5t2い, 而倒心 \\
\hline & $\Rightarrow b l$ & (B)家莱 0 手伝い & RAF要船香 & & \\
\hline
\end{tabular}

図1 研究の方法

表1 調査概要

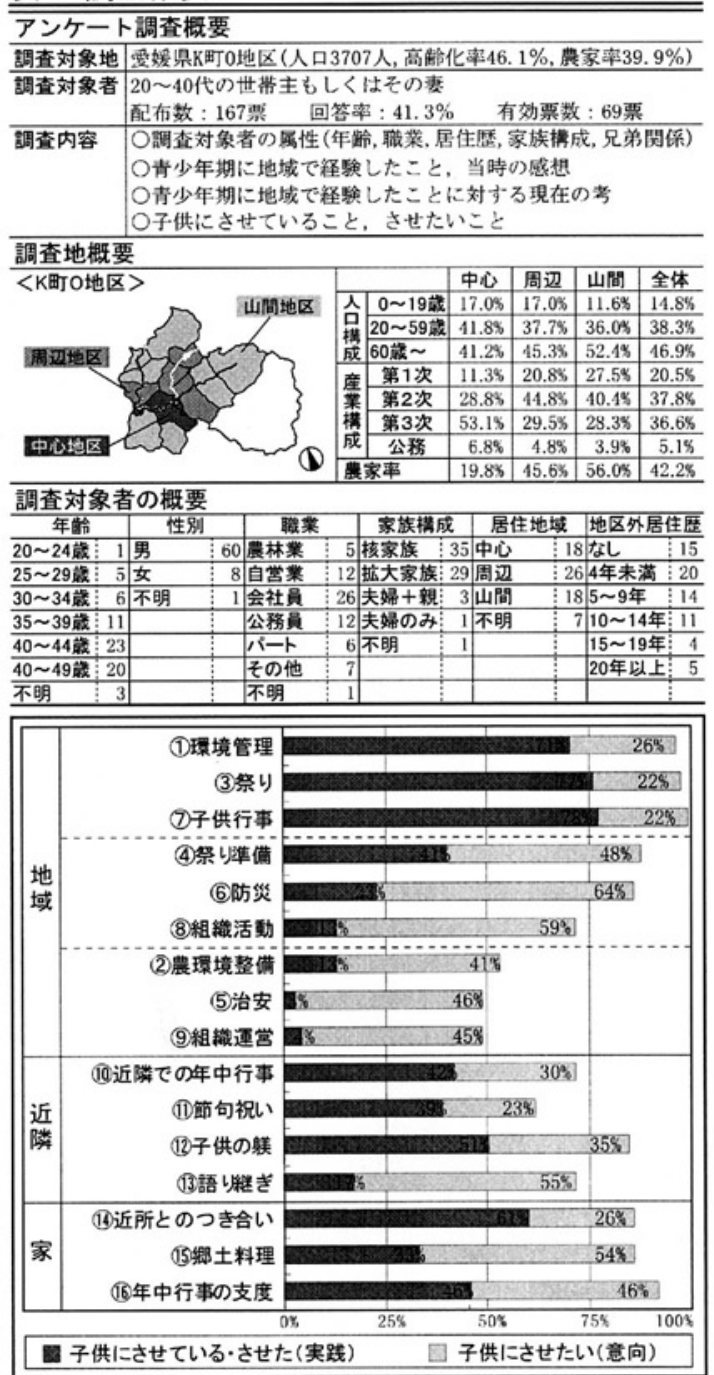

図2 地域に対する価值観の概要 
は，重要性が高く認識されているが，【実践】の 割合は低い。これは, 経験する年齢まで子供が至 っていないことや, 昔体験を話寸役割である年齢 に大人が至っていないことなど, 個々人のライフ ステージの影響が大きい。また, 10近隣での行事, (11)節句等の祝い, (12)子供のしつけ, (15)郷土料理, (16)年中行事の支度でも, 重要性が高く認識されて いるものの【実践】の割合は半数程度となってい るが,これらは子供や親の年齢が特に限定されな いことから, 近隣や家で実践しうる関係があるか どうかが影響している。また, (2)農環境整備, (5) 治安, (9)組織活動は, 必要性に対する認識が低く, 個々人の意識の差が表れている。

以上より, 項目の特徵として, 全体的に実践し ている事項, 意識が高いものの家や地域の状況に よって実践していない事項, 必要性が認識されて いない事項の大きく 3 つ傾向が得られた。

次に, 項目閒の関係性を明らかにするため, 16 項目各 3 段階, 計 48 の変数に対し, 分析単位を個 人として数量化而類を用いて構造化する（図 3)。

I - II 軸のカテゴリープロット図において, 原 点と【必要なし】【意向】【実践】の 3 変数との 位置関係から, 各項目は 4 タイプに分類できる。

【実践】が原点に近い(1)環境管理, (3)祭り, (7)子 供の行事, (14)近隣とのつき合い, 【実践】と【意 向】が原点に近い(11)節句等の祝い, (12)供のしつ け, 13昔話の語り継ぎ, 3 変数が原点からほぼ同 距維にある(4)祭り準備, (6)防災, (10)近隣での)行事, (16)年中行事の支度, 【必要なし】と【意向】が原 点に近い(2)農環境整備, (5)治安, (8)組織活動, (9) 組織運営, 15郷土料理である。原点に近い程回答 者が多いことから, 後述のタイプにある項目ほど その重要性が認識されにくい項目といえる。

さらに, 個々人の地域社会に対する価值観の特 徵を捉えるため, 数量化而類の得点值をもとに調 查対象者をクラスター分析ウォード法により A 1 からA 6 の 6 類型に分類した（図 4)。

カテゴリープロットより, I 軸のマイナス方向 にいく程継承への積極性が高くなることから，A 2 が最も積極的な意識を持つタイプといえる。さ らに,【意向】の方向一広がる A $1 \rightarrow$ A 3 は, 意向 は全体にあるものの実践が少なくなっていく段

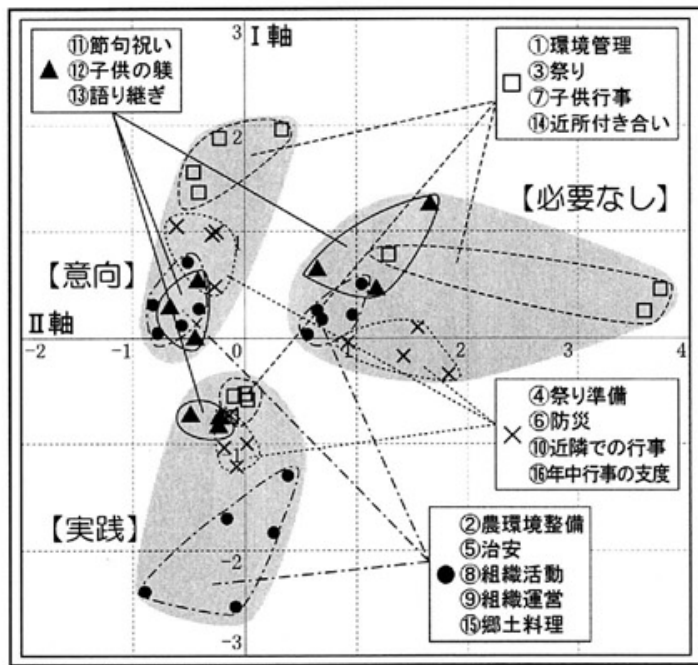

図3 継承姿勢|関するカテゴリープロット
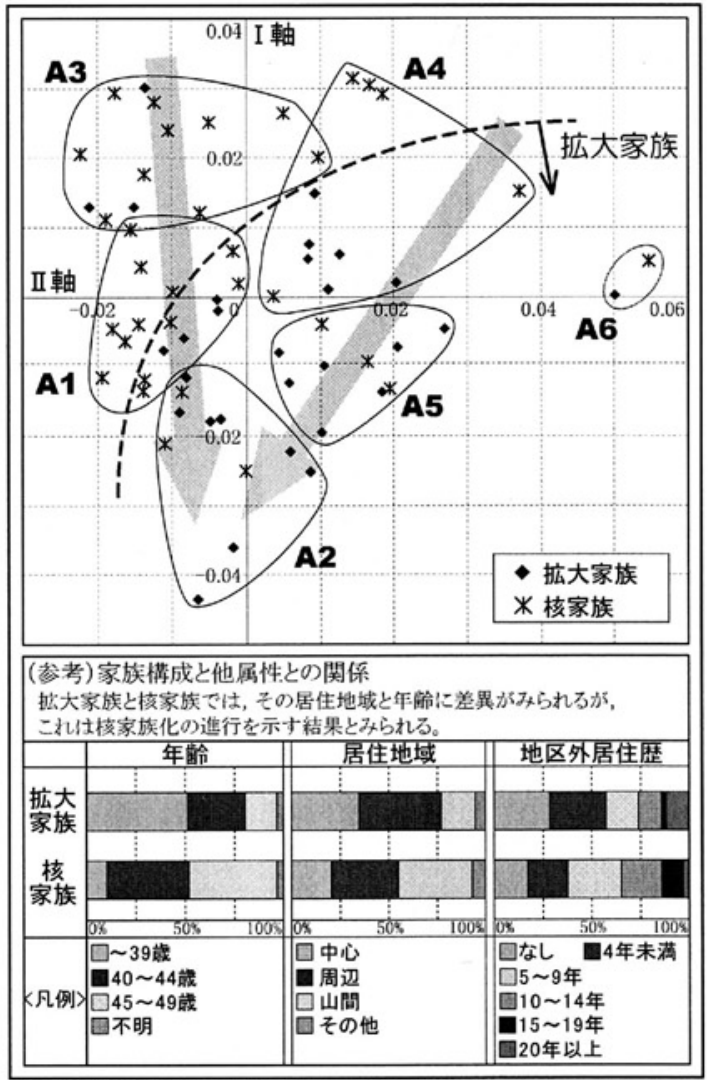

図4 継承姿勢による個人類型と家族構成との関係

階であり,【必要なし】の方向へ広がる A $5 \rightarrow \mathrm{A}$ 4 は, 意向自体が特定の分野に偏っていく段階と して捉えられる。 
これらの類型と個々人が置かれている立場と の関係をみる (図 5)。家族構成をみると, A 3 , A 1 に核家族世帯が多い一方で, A 5, A 2 には 拡大家族世帯が多い。このことから, 前述の $2 つ$ の段階性は家族構成の違いとの関連が強いと予 想される。核家族世帯が多いA $1 \cdot A$ A 3 方が, 全体に意向が高いことは, 核家族の方が世带主と しての自覚を早くから認識することを示してい ると考えられる。さらに, 年齢と居住地域をみる と, A 3 は 39 歳以下の若い世代や中心部居住者 が多い。一方でA 2 - A 5 は, 40 代以降の壮年 層世代, 周辺・山間部居住者の割合が高い。さら に, A 5 は他の地域で長く居住していた人が多い が, 最も意識が高いA 2 は組織経験が豊富な人が 多く,地域を牵引する役割を担っている人物であ ると推測される。

以上より, 次世代への継承姿勢からみた地域に 対する価值観は, 子育ての環境を示す家族構成や 地域性, また個々人のライフステージを示す年齢 により段階的に変化することが捉えられた。

\section{IV 青少年期の経験と価值観との関連性}

前章で捉えた地域に対する価值観と，青少年期 の経験との関連性を捉える。

まず, 青少年期の経験の特徵を捉える (図 6)。 (1)環境管理, (3)祭り, (7)子供の行事, (11)節句等の 祝い, 12)供のしつけ; 13昔話の語り継ぎは, 多 くの人が経験し，かつく+>の意見が多いことか ら, 青少年期に最も馿染みやすい基本的な経験と いえる。一方, (2)農環境整備, (4)祭り準備, (8)組 織活動, (9)組織運営といった地域共同作業に対し てはくー>の意見がみられ, 家でのしつけの一環で ある(14)〜18)はくー>の意見の割合が高い。このこと から, 青少年期の経験には, 子供が馴染みやすい 事柄と, 大人から言われて仕方なくやる事柄の両 方があることが明らかとなった. また，(14)近所と のつき合い, 17)家屋の手入れ, 18家業の手伝いと いう家での経験は,くー>の意見が多い受身の経験 であるものの, 多くの人が経験しており, 地域で 行う(1)(3)(7)と並んで青少年期の基本的な経験と して位置づけられる。

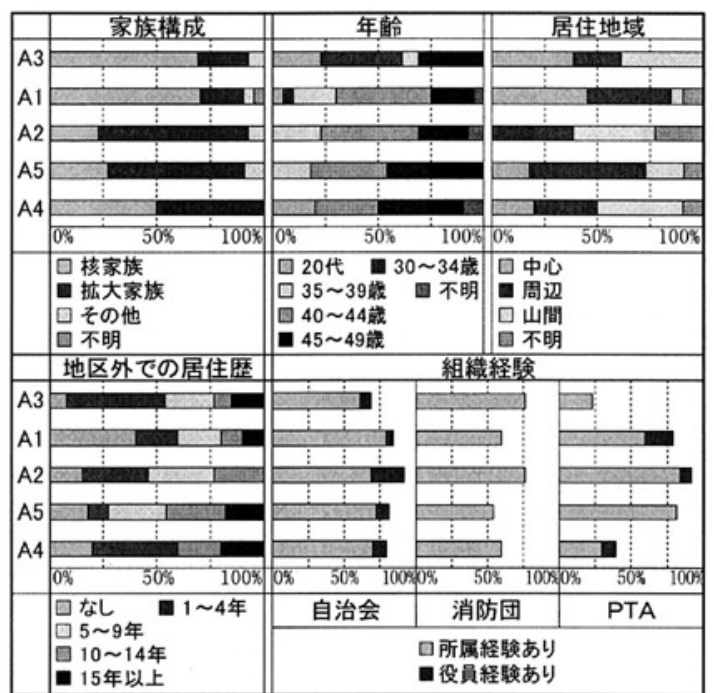

図5 個人類型とおかれている立場との関係

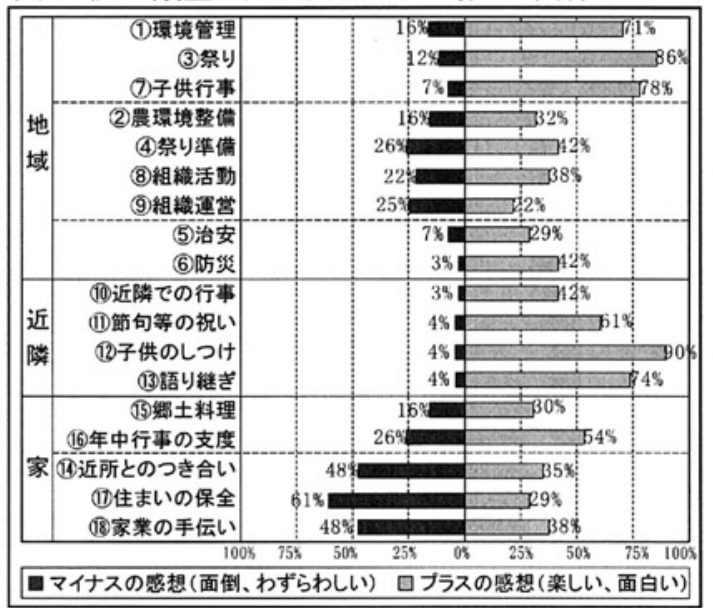

図6 青少年期の経験の概要

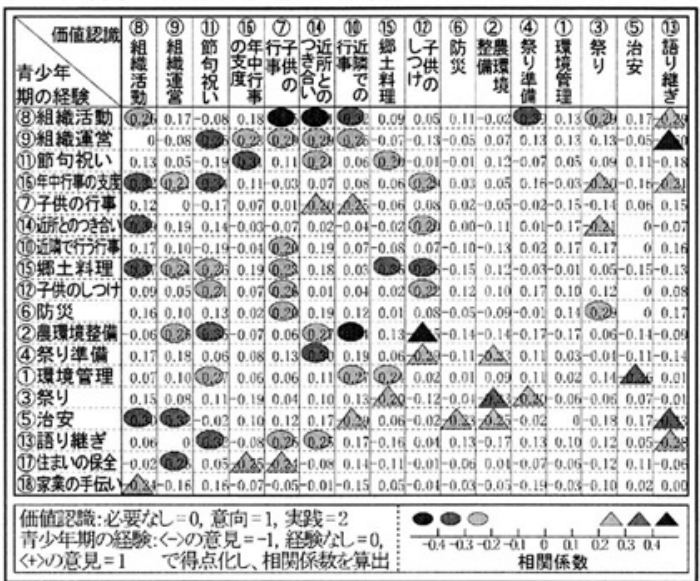

図7 価値観と青少年期の経験との関係 
次に, 青少年期の経験と現在の価値認識との関 係を捉えるため, 前章で用いた継承姿勢の 16 項 目と青少年期の経験 18 項目との項目ごとの関倸 をみる（図７）。同じ内容の項目同士よりも，異 なる内容の項目間の方が高い関連性がみられた。 中でも, 価值観の多くの項目と高い関連性がみら れる経験は, (2)農環境整備, (5)治安, (8)組織活動, (9)組織運営であり,これらは地域に対する価值観 の形成に影響を及ぼす経験と位置づけられる。し かし, 前章の分析結果より重要性が認識されてお らず，見直す必要があるといえる。また，(14)近所 とのつき合い, (15)郷土料理, 16)年中行事の支度と いった家での経験は(8)組織活動との関連が強く, 家や近隣での経験は, 地域運営に対する価值観の 形成に影響があることを示す。

さらに, 前章で捉えた価值観の類型ごとに, 青 少年期の経験をみる（図８）。まず, (1)環境管理, (3)祭り, (7)子供の行事, (12)供のしつけ, (13)昔話 の語り継ぎ, 14住まいの保全は, 類型による差が なく，誰もが共通して経験する事柄といえる。

一方で，類型により差がある項目もみられた。 価値認識の最も高いA 2 に多いのが, (4)祭りの準 備, (5)治安, (6)防災, (10近隣での行事, (11)節句等 の祝い, (15)鄉土料理, (16)年中行事の支度, 18)家業 の手伝いの経験であり, 青少年期に, 地域の裏方 に関わる経験や, 近隣や家での伝統に触れる経験 をしたことが現在の価值認識の高さに影響して いるといえる。また，地域のこと全般に意識の高 いA $3 \cdot$ A $1 \cdot$ A 2 に(8)組織活動, (9)組織運営, (14)近所とのつき合いの経験が多いことから, 地域 や近隣で人との協働関係を持つ経験は地域全体 へと意識を広めるきっかけになるといえる。ま た, (1)環境管理, (8)組織活動に対しては, 20 代 $\sim 30$ 代前半の多い A $3 \cdot \mathrm{A} 1$ で当時くー>の意見 を持っていた者が多い。これは, 少子化の進行に よって一人一人にかかる負担が増したためと類 推される。しかし, A 2 やA 1 - A 3 は当時く一 の意見を持っていた項目に対して, 現在は価值を 認識しており, 時間の経過によって重要性が再認 識されていることを示す。以上より, 個々人の価 值観の持ち方には, 青少年期に経験した内容が影 響していることが捉えられた。

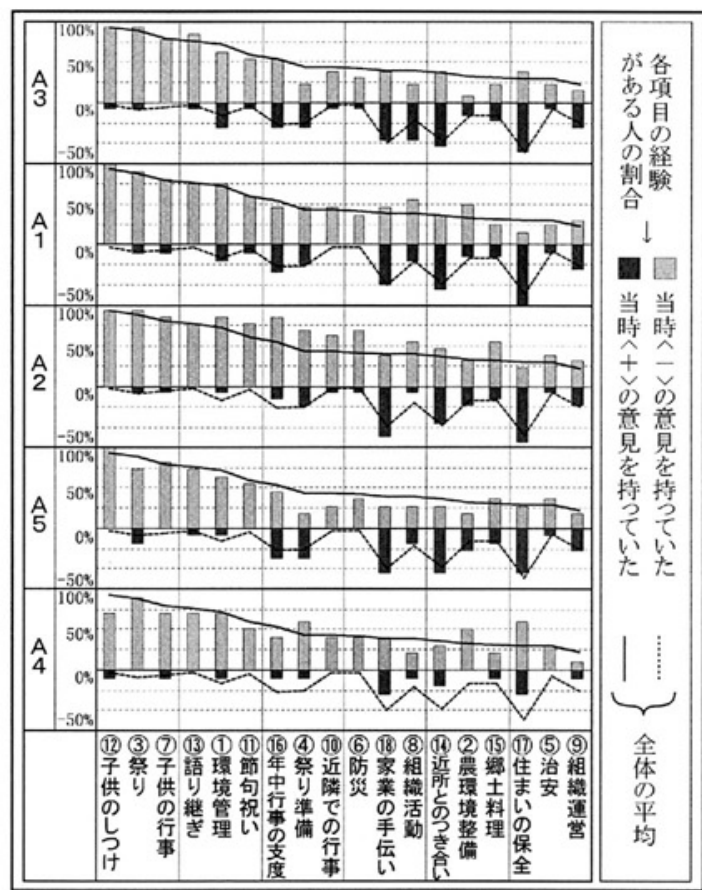

図8 類型別にみた青少年期の経験

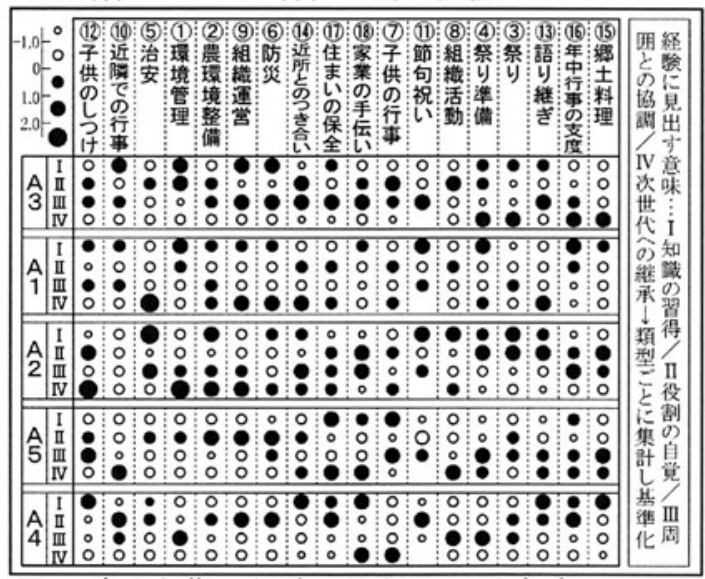

図9 青少年期の経験に見出している意味

\section{V 今後の地域社会生活の担い手育成}

3 章で行った類型化より, 価值観の段階性が核 家族世帯と拡大家族世帯という $2 つ 0$ 家族形態 によって異なることが示された。そこで，この 2 つの段階性の相違点を明らかに寸るため, 家族 構成の違いに着目しながら, 青少年期の経験に対 して現在見出している意味をみる。これにより， 地域社会に対する視点を明らかにする（図9）。 
項目全体を通して, 核家族世帯の多いA 1, A 3 は I . 知識の習得や II . 役割の自覚といった 個々人が身につけるべき基本的な事項を意識し ているが，拡大家族世帯の多いA 5, A 4 はIII. 周囲との協調, IV. 次世代への継承といった, 個 人から集団, また将来へと広い視点から経験を評 価している。このことから，拡大家族のように多 様な世代間関係が家の中にあることは, 地域での 経験に見出す価值を広めることにつながるとい える。よって, 今後の地域社会の担い手を積極的 に育成していくためには, 拡大家族にみられる様 な身近にある世代間での継承関係を地域社会の 中でも築いていくことで, 核家族にも付与してい くことが重要といえる。その一つの方法として, 近年增加する高齢者の核家族世帯が若い核家族 を支えていく体制の検討を提案する。

\section{VI まとめ}

O地区を対象とした分析から, 今後の地域社会 の担い手育成に関して得られた知見をまとめる。

1 ) 地域社会に対する価值認識度 : 地域社会に 対する認識は, まず(1)環境管理, (3)祭り, (7)子供 の行事, (14)近所とのつき合いが最も基本的な事項 として全体に理解されており, その次に, 近隣で の教育や, 行事の準備等の裏方に関わる事項, 最 後に, 地域の運営という根幹に関わる事項, と段 階的に理解されていくことが得られた。

また,このような内容の発展に伴い, 個々人の 価値認識も段階的に進んでいき, 家族構成の状況 や地域性, また個々人のライフステージに応じて 異なることが捉えられた。

2）青少年期の経験が価値観に及ぼす影響 : 現 在の価値認識に関連性の深い経験として, (2)農環 境整備, (5)治安, (8)組織活動, (9)組織運営が抽出
された。これらは，都市化の進行により経験する 機会が減少しつつあるが, 本研究の分析より, 地 域社会に対する理解を深める経験としての潜在的 重要性が導かれた。また, 居住地選択の基準とな る環境面や安全面を維持していくための知識が蓄 積されてきた事項でもあることから，このような 経験の価値を再度見直すことが重要である。

また, 地域社会における経験の中には, 青少年 にとっては消極的に捉えられる面もあるが，後に 重要性が再認識されることもあるため, 長期的視 野を持って経験させていく必要がある。

3 ) 今後の地域社会の担い手育成における課題: 家族構成の違いに着目した考察により，身近な世 代間関係における日常的な継承行為が重要である という知見が得られた。これまでの地域社会にお いては, 家を中心に行われてきた世代循環のシス テムであるが, 今後は, 近隣や地域における世代 間関係の中でも積極的に築いていくことが，今後 の地域社会の担い手育成を促すと考えられる。

\section{参考文献}

1)鈴木榮太郎著作集 I : 鈴木榮太郎, 未来社, 1969 2)菅 原麻衣子, 藍澤宏, 井橋朋子(2005)「農山村地域における 住民の地域社会に関する知識保有と活用実態一高齡社会 型の地域社会における高龄者の役割と参画一」, 農村㖕画 論文集, 23 巻, pp271-276 3)井橋朋子, 藍濢宏, 菅原麻 衣子(2006):「地域社会の価値認識形成における青少年期の 経験の重要性」, 農村計画学会学術研究発表会要旨集, pp3-4 4)鉿木麻衣子, 藍澤宏, 梅田美鈴(2002): 「行事にみ る地域社会の担い手育成の場に関する研究」, 日本建築学 会計画系論文集, NO.560, pp185-192 5) 菅原麻衣子, 藍 澤宏, 篠塚麻衣(2006)「高齢化の進む中山間地域における 地域社会機能とその担い手層の特徽一高齢社会型の地域 社会形成に関する計画研究その 1 -」, 日本建築学会計画 系論文集, NO.600, pp81-88, 6)藍澤宏, 鉿木麻衣子, 斎 尾直子「農村地域における個人・世帯・イエの役割分担と その継承方法に関する研究」, 日本建築学会計画系論文集, NO.535, pp163-170

Recently, some young people in rural area actively participate in their community and liven it up. Thus it is needed that they find the attractiveness of their own living through experience. The purpose of this paper is to show the importance of experience in youth, for raising the value of community. We examine their recognition of which they want to succeed in the future, and grasp its value. In addition, the relation between value and experience is cleared.

In conclusion, it is important to experience the community activities in youth and to play roles of community management corresponding their life stages. 